\title{
MENINGKATKAN KEMAMPUAN BERBICARA BAHASA JEPANG DENGAN PENEKANAN TAHAPAN OUYOURENSHUU DI KELAS X MIPA 1 SMA NEGERI 1 TAMPAKSIRING TAHUN AJARAN 2018/2019
}

\author{
N. M. Darmini ${ }^{1}$ I. W. Sadyana ${ }^{2}$ K. E. K. Adnyani ${ }^{3}$ \\ Program Studi Pendidikan Bahasa Jepang, Jurusan Bahasa Asing, Fakultas Bahasa dan Seni Universitas \\ Pendidikan Ganesha, Singaraja, Bali,Indonesia \\ e-mail: ni.made.darmini@undiksha.ac.id wayan.sadnyana@undiksha.ac.id \\ krishna.adnyani@undiksha.ac.id
}

\begin{abstract}
ABSTRAK
Penelian ini bertujuan untuk mengetahui (1) penerapan penekanan tahapan ouyourenshuu untuk meningkatkan kemampuan berbicara dalam bahasa Jepang siswa kelas $X$ MIPA 1 SMA Negeri 1 Tampaksiring Tahun Ajaran 2018/2019, dan (2) respons siswa terhadap penerapan penekanan tahapan ouyourenshuu dalam pembelajaran bahasa Jepang. Subjek penelitian ini adalah siswa kelas X MIPA 1 SMA Negeri 1 Tampaksiring yang berjumlah 33 orang. Metode pengumpulan data yang digunakan pada penelitian ini adalah tes, observasi, angket, dan wawancara. Hasil penelitian ini menunjukkan bahwa (1) penekanan tahapan ouyourenshuu dapat meningkatkan kemampuan berbicara bahasa Jepang siswa. Hal tersebut ditunjukan dengan adanya peningkatan persentase ketuntasan klasikal dari $18,18 \%$ pada pre-test menjadi $87,87 \%$ pada siklus I dan meningkat menjadi $100 \%$ pada siklus II melebihi target persentase ketuntasan kelas yang ditetapkan yaitu $75 \%$ dan (2) siswa memberikan respons positif dari penekanan tahapan ouyourenshuu dalam meningkatkan kemampuan berbicara bahasa Jepang yaitu pembelajaran menjadi menyenangkan dan kemampuan berbicara lebih meningkat dari sebelumnya. Berdasarkan hasil tersebut dapat disimpulkan bahwa penerapan penekanan tahapan ouyourenshuu efektif untuk meningkatkan kemampuan berbicara bahasa Jepang siswa kelas X MIPA 1 SMA Negeri 1 Tampaksiring.
\end{abstract}

Kata Kunci : tahapan ouyourenshuu, , kemampuan berbicara

本研究の目的は 1) 2018/2019 年度タンパクシリン第一国立高等学校理科学科一年生の日本語授業に おける日本語会話力を向上するための応用練習流れの強調するを知ること、2）日本語の授業におけ る応用練習流れの強調に対して、学習者がどのように反応するかを明らかにすることである。調查協 力者は 2018/2019 年度タンパクシリン第一国立高等学校理科学科一年生、33 名である。調査対象は、 テスト、観察、アンケート、及びインタビューにより収集したデータである。応用練習流れの強調に おいて、1)学習者の合格率が向上であることが分かった。事前テストでは $18,18 \%$ あったが、一回 目のサイクルでは 87.87\%に達した。さらに、二回目のサイクルでは $100 \%$ 、合格率が平準合格率 (75\%) を超えた。2)日本語会話力を向上するための応用練習流れの強調に対して、学習者はポジテ イブな反応をした。学習者は授業に関心が向上し、会話力も向上したであることが分かった。つまり、 2018/2019 年度タンパクシリン第一国立高等学校理科学科一年生の日本語授業における日本語会話力 を向上寸るための応用練習流れの強調は、日本語会話力の向上の効果的であると言える。

キーワード：応用練習流れ、会話力 


\section{PENDAHULUAN}

Kemampuan berbicara adalah kemampuan mengucapkan bunyi-bunyi artikulasi atau mengucapkan kata-kata untuk mengekspresikan, menyatakan, menyampaian pikiran, gagasan, dan perasaan (Arsjad dan Mukti, 1993 : 17). Dengan memiliki kemampuan berbicara menggunakan bahasa asing khususnya bahasa Jepang, siswa diharapkan mampu menggunakan bahasa tersebut dalam situasi yang sebenarnya di lingkungan masyarakat. khususnya pada era globalisasi seperti sekarang ini, hal tersebut menjadi kebutuhan mutlak dalam mempelajari bahasa asing. Kurangnya pemahaman siswa dan adanya perasaan malu dan takut salah harus dihilangkan untuk dapat meningkatkan kemampuan berbicara siswa dalam mengunakan bahasa Jepang. Ada beberapa faktor yang mempengaruhi efektivitas proses belajar mengajar di kelas yaitu sikap siswa, kemampuan dan gaya mengajar, keyakinan guru, pengetahuan, kemampuan guru pada situasi atau konteks pembelajaran, keterlibatan siswa, kolaborasi siswa, dan penekanaan pada kompetensi yang dicapai oleh siswa (Padmadewi, 2012: 11).

Hal ini menyebabkan timbulnya tahapan ouyourenshuu pengajaran yang efektif. Seperti guru mulai menggunakan media pembelajaran, meningkatkan kemampuan dalam mengajar serta menjelaskan materi dengan sebaik-baiknya. Pada pembelajaran bahasa Jepang di SMA/SMK/MA, masalah yang banyak ditemui adalah siswa mengetahui suatu kalimat yang benar dalam bahasa asing, tetapi tidak mampu berbicara menggunakan bahasa tersebut. Hal ini membuat guru merasa kekurangan waktu dalam melatih kemampuan berbicara siswa. Pada umumnya dalam mengikuti pelajaran siswa merasa canggung dan takut salah dalam menggunakan bahasa Jepang. Fenomena ini diketahui ketika dilakukan observasi di dalam kelas dan wawancara awal dengan guru pengampu mata pelajaran bahasa Jepang di SMA Negeri 1 Tampaksiring. Ketika diwawancarai terkait dengan kemampuan berbicara siswa guru mengatakan bahwa saat guru mengajukan pertanyaan komunikatif menggunakan bahasa Jepang, namun tidak semua siswa bisa mampu menjawab pertanyaan bahkan ada juga beberapa siswa yang masih melihat buku pelajaran saat menjawab pertanyaan yang diajukan guru. Adapun metode pengajaran yang ditawarkan dan diharapkan mampu membangkitkan motivasi serta minat siswa terhadap pembelajaran bahasa Jepang yaitu tahapan ouyourenshuu. Tahapan ini diharapkan mampu meningkatkan kemampuan siswa dalam berbicara menggunakan bahasa asing secara komunikatif. tahapan ouyourenshuu mempunyai prinsip bahwa bahasa diperoleh melalui proses komunikasi, jadi bukan hanya mengaktifkan pengetahuan tentang bahasa yang dimiliki dan telah ada didalam diri siswa tetapi merangsang pengembangan sistem bahasa itu sendiri (Padmadewi, 2012 :69).

\section{METODE PENELITIAN}

Metode penelitian pada prinsipnya adalah prosedur atau cara yang ditempuh dalam penelitian (Wendra, 2012 :52). Melalui metode penelitian yang dipertangung jawabkan. Metode penelitian bertujuan untuk menemukan atau memperoleh suatu masalah dengan cara menerapkan suatu metode dengan berbagai hal yang dibahas. Langkah-langkah yang dilakukan secara sistematis untuk mendapatkan pengetahuan ilmiah dalam pembahasan ini mencangkup enam subbab. (1) Rancangan Penelitian. (2) Lokasi Penelitian. (3) Sumber Data. (4) Prosedur Pelaksanaan Penelitian. (5) Metode Pengumpulan Data dan Instrumen Penelitian. (6) Teknik Analisis Data dan Kriteria Keberhasilan. Langkah-langkah yang dilakukan secara sistematis untuk mendapatkan pengetahuan ilmiah dalam pembahasan ini mencangkup enam subbab. (1) Rancangan Penelitian. (2) Lokasi Penelitian. (3) Sumber Data. (4) Prosedur Pelaksanaan Penelitian. (5) Metode Pengumpulan Data dan Instrumen Penelitian. (6) Teknik Analisis Data dan Kriteria Keberhasilan. 


\section{Rancangan Penelitian}

Penelitian ilmiah yang akan dilakukan hendaknya menyusun suatu langkah-langkah pelaksanaanya melalui rancangan penelitian. Penelitian ini merupakan penelitian tindakan kelas (PTK) yang rancangan penelitian yakni bersiklus (multi siklus). Pada kegiatan setiap siklusnya meliputi refleksi awal, perencanaan tindakan, pelaksanaan tindakan, obsevasi/evaluasi dan refleksi. Penelitian tindakan kelas ini akan dilaksanakan melalui beberapa siklus sampai tujuan penelitian tercapai. Alasan peneliti mengadakan penelitian tindakan kelas karena terdapat masalah di dalam sebuah kelas. Tentang kurangnya kemampuan berbicara bahasa Jepang siswa X MIPA 1 SMA Negeri 1 Tampaksiring, untuk mengatasi masalah tersebut dilakukan penelitian untuk mengamati perubahan perilaku siswa dan mengidentifikasi fakta-fakta yang menyebabkan permasalahan tersebut terjadi.

Setiap penelitian memiliki kelebihan dan keterbatasan. Penelitian tindakan kelas juga memiliki kelebihan dan keterbatasan dalam penerapannya. Menurut Sanjaya (2009) kelebihan penelitian tindakan kelas adalah : pertama, PTK dilakukan secara kolaboratif dengan melibatkan guru sebagai pelaksanaan tindakan sekaligus sebagai peneliti, observasi baik yang dilakukan oleh guru lain sebagai teman sejawat atau orang lain, ahli penelitian yang biasanya orang-orang LPTK dan siswa itu sendiri. Kedua, kerjasama merupakan ciri lhas dari PTK yang menghasilkan sesuatu yang lebih kreatif dan inovatif. Ketiga, hasil atau simpulan, yang diperoleh merupakan kesepakatan dari semua pihak khususnya antara penelitian dan mitranya yang akan meningkatkan validitas dan reabilitas hasil penelitian dan yang terahir hasil yang diperoleh dapat secara langsung ditetapkan oleh guru. Sanjaya (2009) juga menyatakan keterbatasan PTK antara lain: pertama, peneliti dalam melakukan penelitian cenderung konvensional, penelitian sulit mengubah kebiasaan mengajar dan beranggapan tugas terbatas pada pelaksanaan mengajar. Kedua, peneliti mengangkat praktis masalah dari guru yang dihasilkan tidak bersifat universal. Ketiga, PTK merupakan penelitian yang bersifat situasional dan kondisional terkadang tidak menerapkan prinsip-prinsip metode ilmiah secara teratur.

Dari pernyataan menurut Sanjaya (2009), pelaksanaan PTK yang dilakukan dalam pelaksanaan secara nyata berbeda, diantaranya adalah guru pengampu mata pelajaran bahasa Jepang bukan sekaligus sebagai peneliti melainkan guru diajak untuk berkalaborasi dalam penyelesaian masalah. Hal tersebut dikarenakan, guru lebih memahami karakter siswa yang dijadikan sebagai subjek penelitia. Maka kolaborasi yang terlibat dalam penelitian ini ada 3 faktor, diantaranya guru sebagai penyelenggara pendidikan, peneliti sebagai pengajar yang menerapkan tahapan ouyourenshuu dengan dan siswa sebagai subjek

\section{Lokasi Penelitian}

Penelitian ini dilakukan di salah satu sekolah menengah atas yaitu SMA Negeri 1 Tampaksiring tahun ajaran 2018/2019 yang beralamat di Jalan Pucak Tegeh Manukaya, Tampaksiring, Manukaya, Kec. Gianyar, Kabupaten Gianyar, Bali 80552.

\section{Sumber Data}

a) Subjek Penelitian

Subjek penelitian merupakan variabel yang akan diteliti dalam suatu karya ilmiah. Dalam penelitian ini yang menjadi subjek penelitian adalah siswa di kelas X MIPA 1 SMA Negeri 1 Tampaksiring. Tempat yang dijadikan penelitian adalah SMAN 1 Tampaksiring. Jumlah siswa kelas X MIPA 1 yaitu 33 orang.

b) Objek Penelitian

Objek penelitian dibedakan atas dua macam, yaitu pertama, objek yang mencerminkan proses, dan proses yang mencerminkan produk (Wendra, 2012 :54). 


\section{Prosedur Pelaksanaan Penelitian}

Dalam prosedur pelaksanaan penelitian tindakan kelas (PTK) dilakukan berdasarkan beberapa siklus. Menurut Latief (2009) setiap satu siklus pada penelitian tindakan kelas dilaksanakan 2 kali pertemuan atau lebih, hal tersebut tergantung pada besaran materi pembelajaran setiap standar kompetensi, kompetensi dasar, ketersediaan waktu, serta perbaikan yang sesuai harapan. Berdasarkan teori tersebut setiap satu siklus akan dilaksanakan tiga kali pertemuan, 2 kali pertemuan untuk melaksanakan proses pembelajaran dan 1 kali pertemuan untuk mengadakan evaluasi.
a) Tahap Perencanaan
b) Tahap Pelaksanaan
c) Observasi
d) Refleksi.

Berlangsunya proses pembelajaran menggunakan tahapan ouyourenshuu. tahapan ouyourenshuu diterapkan pada kegiatan inti, sedangkan media audio visual diterapkan pada mkegiatan inti juga dengan membantu menjelaskan materi agar lebih menarik. Berlangsungnya setiap pelaksanaan pembelajaran diikuti dengan pengisian lembar observasi siswa. Pada pelaksanaan evaluasi menghasilkan tiga hasil yaitu, hasil belajar siswa yang diperoleh dari post-test, hasil respons siswa yang diperoleh dari kuesioner, dan hasil wawancara yang dilakukan dengan 6 siswa yang dipilih berdasarkan kemampuan berbicara bahasa Jepang tinggi, sedang, dan rendah. Selain atas dasar keempat kategori penentuan pertemuan tersebut, landasan ditentukannya pertemuan dalam siklus trgantung pada satu unit metode dan media yang direncanakan.

Pelaksanaan satu siklus terdiri dari empat (4) langkah yaitu, kegiatan perencanaan, pelaksanaan, pengamatan dan refleksi. Setelah siklus I dilaksanakan, walaupun kriteria ketuntasan telah tercapai penelitian ini akan dilanjutkan ke siklus II. Hal ini dilakukan untuk memvalidasi data yang diperoleh. Namun, jika setelah siklus II belum menunjukan hasil yang sesuai dengan kriteria keberhasilan maka akan dilanjutkan ke siklus selanjutnya. Siklus ini dilakukan berulang- ulang sehingga hasil yang diperoleh mencapai kriteria keberhasilan. Ketika sudah menunjukan hasil yang sesuai dengan kriteria keberhasilan maka penelitian dapat dihentikan. Apabila telah menunjukkan kriteria ketuntasan maka diharapkan penerapan tahapan ouyourenshuu dapat meningkatkan kemampuan berbicara bahasa Jepang kelas X MIPA 1 SMAN 1 Tampaksiring.

\section{Metode Pengumpulan Data dan Instrumen Penelitian}

Metode pengumpulan data menekankan secara lebih spesifik tentang cara mengumpulkan data (Wendra, 2012 : 57). Metode pengumpulan data yang digunakan dalam penelitian ini adalah tes lisan, observasi dan kuesioner, wawancara. Observasi digunakan untuk mengetahui sejauh mana penerapan tahapan ouyourenshuu pada pembelajaran bahasa Jepang. Sedangkan, tes lisan digunakan untuk mengetahui kemampuan siswa dalam berbicara bahasa Jepang. Kuesioner digunakan untuk mengetahui respons siswa dalam penerapan metode Pengajaran tahapan ouyourenshuu dan wawancara digunakan untuk mentiangulasi data.

\section{Teknik Analisis Data dan Kriteria Keberhasilan}

a) Teknik Analisis Data

Data yang diperoleh dalam penelitian ini dianalisis secara kuantitatif, namun tidak semua data dianalisis secara kuantitatif. Analisis kuantitatif digunakan untuk meningkatkan hasil belajar siswa sebagai pengaruh dari setiap tindakan yang dilakukan guru (sanjaya,2009:117). Untuk menggambarkan data yang sebenarnya dianalisis secara deskriptif kualitatif. Analisis data kualitatif digunakan untuk menentukan peningkatan proses belajar khususnya berbagai tindakan dilakukan guru (Sanjaya, 2009: 117). 
b) Kriteria Keberhasilan

Kriteria keberhasilan dari wawancara dan angket respons siswa ditunjukan oleh presentase siswa yang memiliki respons positif terhadap metode Pengajaran Bahasa Komunikatif yang diterapkan dalam meningkatkan keterampilan berbicara. Respons positif dalam angket diketahui dari banyaknya pendapat siswa yang menyatakan setuju dan tidak setuju dalam mengisi angket. Respons negatif dinyatakan apabila siswa banyak yang tidak setuju dalam penerapan tahapan ouyourenshuu.

Kriteria keberhasilan dari wawancara dan angket respons siswa ditunjukan oleh presentase siswa yang memiliki respons positif tahapan ouyourenshuu yang diterapkan dalam meningkatkan keterampilan berbicara. Respons positif dalam angket diketahui dari banyaknya pendapat siswa yang menyatakan setuju dan tidak setuju dalam mengisi angket. Respons negatif dinyatakan apabila siswa banyak yang tidak setuju dalam penerapan metode Pengajaran Bahasa Komunikatif. Penelitian mengenai respons siswa dianggap berhasil apabila $75 \%$ siswa, jumlah siswa memberikan respons positif. Sangat setuju diberikan skor 5 , setuju diberikan skor 4, cukup setuju diberikan skor 3 , kurang setuju diberikan skor 2 dan skor 1 untuk tidak setuju. Untuk mengetahui kriteria penggolongan respons siswa diperlukan aspek- aspek pendukung yaitu skor rata-rata respons siswa $(\mathrm{X})$, mean ideal (Mi), dan Standar Deviasi Ideal (SDI). Untuk mengkonversikan skor mentah menjadi skor standar dengan norma absolut skala seratus (presentil) digunakan rumusan sebagai berikut:

$$
\mathrm{N}=\frac{\mathrm{X}}{\mathrm{SMI}} \times 100
$$

Untuk menemukan nilai rata - rata kelas menggunakan rumusan sebagai berikut:

Nilai rata - rata $($ mean) kelas $=$

Jumlah nilai seluruh siswa Jumlah siswa

\section{HASIL DAN PEMBAHASAN}

Sebelum tindakan kelas dilakukan langkah yang ditempuh adalah mengetahui kondisi awal kemampuan berbicara bahasa Jepang siswa. Data ini diperoleh dengan melaksanakan pre-test lisan kepada semua responden. Pre-test lisan ini dilaksanakan pada hari selasa, 26 Maret 2019 pada jam 1-3. Awalnya siswa diminta untuk berada di luar kelas, setelah itu dipanggil siswa satu persatu untuk melakukan tes lisan. Setiap siswa diberikan waktu menjawab pertanyaan selama 3 menit. Setelah siswa selesai menjawab soal, setelah itu dipanggil siswa selanjutnya. Hal ini berlanjut hingga semua siswa telah melaksanakan tes lisan.

nilai hasil pre-test terkait dengan kemampuan berbicara bahasa Jepang siswa menunjukan 1 orang siswa $(3,03 \%)$ mendapat nilai 75 , sebanyak 5 orang siswa $(15,15 \%)$ mendapat nilai 70 , sebanyak 4 orang $(12,12 \%)$ mendapat nilai 65 , sebanyak 11 siswa $(33,33 \%)$ mendapat nilai 60 , sebanyak 6 siswa $(18,18 \%)$ mendapat nilai 55 , sebanyak 6 siswa $(18,18 \%)$ mendapat nilai 50 . Nilai rata-rata yang didapatkan oleh siswa adalah 2,387 dalam katagori sangat kurang. Untuk lebih jelasnya nilai pre-test siswa akan disajikan dalam bentuk gambar 1 . 


\section{Nilai Pre -Test Siswa}

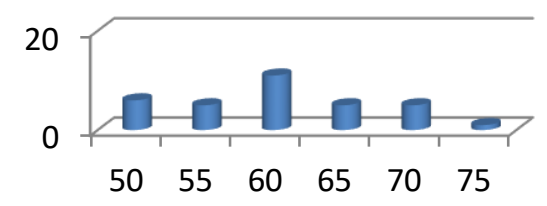

Gambar. 1, nilai pre-test

Setelah tindakan siklus I yang terdiri dari dua kali pembelajaran telah dilaksanakan, diperoleh hasil post-test yang diberikan kepada siswa untuk mengukur kemampuan siswa dalam berbicara mengunakan bahasa Jepang. Dengan menerapkan tahapan ouyourenshuu diterapkan pada pembelajaran di kelas. Tes dilaksanakan pada hari Selasa 23 April 2019 di kelas X MIPA 1 dengan jumlah siswa sebanyak 33 siswa. Tes yang diberikan berupa tes lisan yang jumlah soalnya ada 10 soal yang harus di jawab siswa secara langsung. Waktu menjawab post-test setiap siswa diberikan waktu selama 3 menit untuk menjawab tes lisan. Namun pada siklus I ada 4 orang siswa yang belum tuntas oleh karena itu akan di perbaiki pada siklus II. Dilakukanya wawancara untuk mengetahui penyebab siswa yang tidak tuntas tersebut. Hasil siklus I bisa dilihat pada gambar 2.

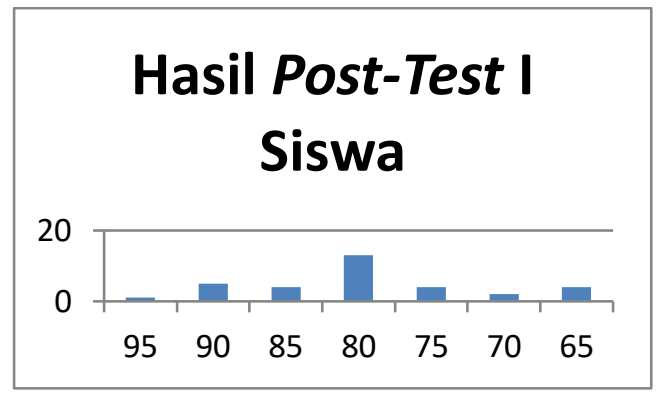

Gambar. 3, post-test I

Untuk mengetahui kemampuan siswa dalam berbicara bahasa Jepang setelah diterapkanya tahapan ouyourenshuu dengan berbantuan media audio visual, diadakan tes lisan terhadap responden. Bentuk pos-test II ini sama dengan pos-test lisan yang telah dilakukan sebelumnya. pos-test II dilaksanakan pada hari selasa, 14 Mei 2019 di kelas X MIPA 1 dengan jumlah siswa sebanyak 33 siswa. Tes yang diberikan berupa tes lisan yang jumlah soalnya ada 10 soal yang harus di jawab siswa secara langsung. Waktu menjawab post-test setiap siswa diberikan waktu selama 3 menit untuk menjawab tes lisan. Hasil nilai pada siklus II bisa dilihat pada gambar 3 .

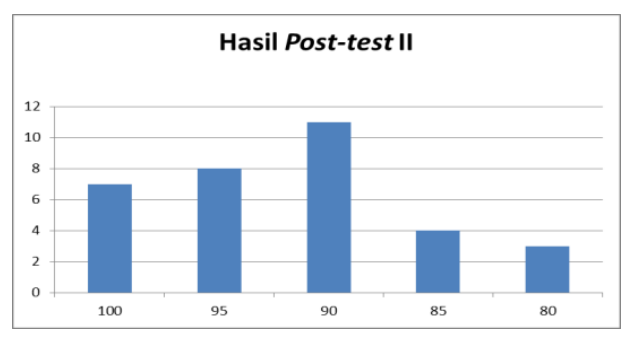

Gambar. 2, hasil post-test

Pada perbandingan nilai pre-test dengan post-test siklus I siswa kelas X MIPA 1 SMA Negeri 1 Tampaksiring peningkatan nilai yang diperoleh siswa kelas X MIPA 1 SMA Negeri 1 Tampaksiring. Pada pre -test ketuntasan nilai yang diperoleh adalah $18,18 \%$ 
sedangkan pada post-test siklus I diperoleh $87,87 \%$. Sedangkan pada siklus II Berdasarkan hasil post-test siklus II yang telah dilaksanakan, diperoleh hasil bahwa siswa yang tuntas sebanyak 33 orang (100\%) pada hasil post-test siklus II tidak ada siswa yang memperoleh nilai di bawah KKM ( $0 \%)$. Dari hasil post-test, post-test I, dan post-test II telah terjadi peningkatan dalam penggunaan tahapan ouyourenshuu. Berdasarkan perbandingan nilai pre-test, post-test siklus I, dan post-test siklus II disajikan dalam gambar 4.

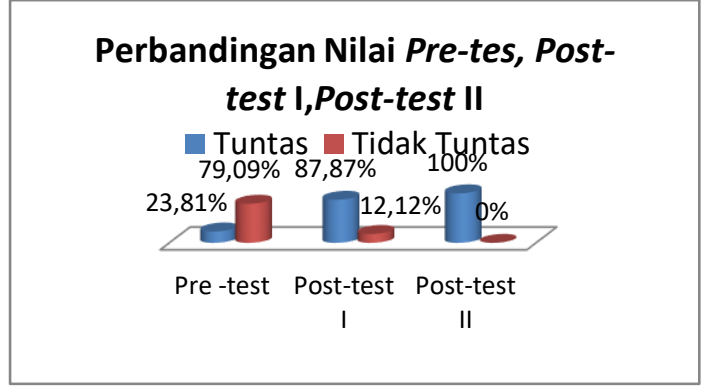

Gambar. 4, perbandingan nilai pre-tes, post-test, post-test.

Berdasarkan gambar 5, perbandingan hasil pre-test, post-test II, dan post-test II dapat dipaparkan sebagai berikut, ketuntasan nilai pada pre-test terhadap KKM hanya $23,81 \%$, pada post-test siklus I mengalami peningkatan menjadi $87,87 \%$, sedangkan perolehan ketuntasan nilai pada post-test siklus II meningkat sebesar 100\%. Dari pemaparan tersebut dapat disimpulkan bahwa, Penerapan tahapan ouyourenshuu mempengaruhi hasil belajar siswa. Hal tersebut terlihat dari peningkatan nilai yang diperoleh oleh siswa dalam berbicara menggunakan bahasa Jepang.

Berdasarkan hasil observasi, post-test II, kuesioner, dan wawancara yang telah dilaksanakan pada siklus II dapat disimpulkan bahwa pelaksanaan tindakan pada siklus II telah terlaksana dengan baik. Hal tersebut dilihat dari terjadinya peningkatan yang signifikan dari hasil belajar siswa dari hasil belajar siswa dan dari respons siswa. Dilihat dari hasil belajar siswa pada pre-test diperoleh ketuntasan klasikal sebesar 18,18\%, pada post-test I mengalami peningkatan yang signifikan menjadi $87,87 \%$, dan pada post-test II kembali mengalami peningkatan yang signifikan menjadi $100 \%$. Sedangkan, respons siswa pada siklus II terhadap penerapan tahapan ouyourenshuu adalah positif.

Peningkatan yang terjadi pada siklus II disebabkan karena proses pembelajaran telah berlangsung dengan prosedur perencanaan pembelajaran yang telah dirumuskan, pengelolaan kelas dengan baik, penerapan metode pengajaran tahapan ouyourenshuu telah sesuai, serta memperbaiki kendala-kendala yang terjadi pada siklus I. perbaikan yang dilakukan pada siklus II menunjukan siswa memperoleh ketuntasan yang maksimal.

Dilihat dari hasil pelaksanaan siklus I dan siklus II, secara garis besar perolehan hasil belajar seluruh siswa kelas X MIPA 1 SMA Negeri 1 Tampaksiring meningkat, bahkan pada hasil belajar di siklus II seluruh siswa memperoleh nilai diatas KKM dengan ketuntasan klasikal 100\%. Dari hasil belajar yang diperoleh dapat disimpulkan bahwa terdapat peningkatan nilai dari hasil belajar siswa, diataranya 1) peningkatan yang drastis, contohnya pre-test memeroleh 18,18 , , post-test I memeroleh 87,87 , dan post-test II memeroleh 100,2$)$ peningkatan yang standar, contohnya pre-test memeroleh 55 , post-test I memeroleh 65, dan post-test II memeroleh 80 , dan 3) peningkatan yang normal dengan contoh pre-test memeroleh 70, , post-test I memeroleh 90, dan post-test II memeroleh 100. Hal tersebut membuktikan bahwa, kecenderungan penerapan tahapan ouyourenshuu lebih berpengaruh kepada siswa yang memperoleh peningkatan yang drastis. Sehingga penerapan tahapan ouyourenshuu cocok digunakan pada karakteristik siswa heterogen. karakteristik tersebut seperti, perbedaan kemampuan berbicara mengunakan bahasa Jepang rendah dan tinggi. 
Berdasarkan temuan dan teori pendukung penelitian ini, peningkatan yang terjadi pada hasil belajar siswa di siklus II memang terbukti dari rata-rata yang di peroleh yaitu 91,67 dengan ketuntasan klasikal 100\%, sedangkan rata-rata yang diperoleh pada siklus I adalah 79,09 dengan ketuntasan klasikal yaitu 87,87\%. Hasil temuan belajar siswa ini diperkuat oleh simpulan dari Ghazali (2010 : 249) yang menyimpulkan bahwa tahapan ouyourenshuu menunjukan adanya peningkatan terhadap rata- rata hasil belajar siswa, walaupun subjek dan objek berbeda dalam penilitian tersebut berbeda tetapi tujuan yang sama yaitu meningkatkan kemampuan berbicara siswa.

Setelah pertemuan setiap siklus dilaksanakan, dilanjutkan dengan disebarkannya kuesioner dan dilakukan wawancara untuk mengetahui respons siswa. Kuesioner siberikan kepada seluruh siswa kelas X MIPA 1 dengan jumlah 33 orang. Setiap kuesioner terdiri dari kuesioner terbuka dan tertutup dengan 10 soal dan kuesioner terbuka dengan 3 soal. Rata-rata yang diperoleh dari kuesioner siklus I adalah 41,48, sedangkan rata-rata kuesioner siklus II yang diperoleh adalah 41,93. Dari hasil kuesioner tersebut dapat digolongkan siswa merespons penerapan metode pengajaran tahapan ouyourenshuu dengan positif.

Pada siklus I terdapat sedikit kesulitan yang dialami oleh siswa, namun hal tersebut dapat diatasi pada siklus II sehingga pada siklus II tidak terdapat kesulitan yang terjadi selama pelaksanaan pembelajaran. Sedangkan kegunaan yang didapatkan siswa dari siklus I sampai siklus II direspons dengan positif seperti, peningkatan kemampuan berbicara bahasa Jepang siswa, ingatan terhadap materi yang disampaikan lebih lama, dan mudah dipahami dari penjelasan yang disampaikan. Pernyataan itu didukung Sudana (2017) yang menyatakan bahwa kendala pada siklus I tidak muncul kembali pada siklus II karena telah diperbaiki, serta manfaat yang dirasakan oleh siswa dari penelitian tersebut adalah dapat berbicara mengunakan bahasa Jepang tanpa ada rasa takut salah dalam berkomunikasi menggunakan bahasa Jepang dan pembelajaran menjadi lebih menyenangkan.

Berdasarkan pada temuan penelitian yang dilakukan di kelas X MIPA 1 SMA Negeri 1 Tampaksiring pada mata pelajaran bahasa Jepang dengan menggunakan tahapan ouyourenshuu untuk meningkatkan kemampuan berbicara bahasa Jepang siswa. Hal tersebut ditunjukan pada hasil belajar siswa yang mengalami peningkatan dari siklus I sampai dengan siklus II karena diterapkannya tahapan ouyourenshuu. Tercapainya keberhasilan dalam proses pembelajaran tidak terlepas dari persiapan sebelum dilakukanyya pembelajaran seperti merancang RPP yang sesuai dengan kurikulum yang diterapkan di kelas X MIPA 1 yaitu K13, mengikuti langkah-langkah pembelajaran tahapan ouyourenshuu, serta menyiapkan perlengkapan lain sebagai sarana pendukung kelancaran proses pembelajaran yang tidak terlepas dari tujuan pembelajaran.

Salah satu faktor yang mempengaruhi terjadinya peningkatan hasil belajar siswa dalam suatu proses pembelajaran dikarenakan materi yang diberikan mampu disampaikan dengan baik serta didukung dengan metode pengajaran bahasa komunikatif dan media audio visual serta disesuaikan dengan karakteristik atau kebutuhan siswa agar tercapainya tujuan pembelajaran. maka dari itu sebelum diterapkannya tahapan ouyourenshuu di kelas $X$ MIPA 1 dilakukan wawancara dan observasi untuk mengetahui karakteristik siswa kelas $X$ MIPA 1. Karakteristik awal siswa kelas X MIPA 1 adalah kurang berani berbicara mengunakan bahasa Jepang, kurang mampu memanfaatkan waktu untuk latihan berbicara menggunakan bahasa Jepang, kurangnya kemampuan berbicara siswa serta kurang berani dan kurang percaya diri dalam berbicara menggunakan bahasa Jepang hal tersebut karena kurangnya motivasi yang diberikan kepada siswa.

Penerapan tahapan ouyourenshuu akan membantu siswa untuk memahami materi khususnya kemampuan berbicara siswa dengan baik. Tahapan tahapan ouyourenshuu berpusat kepada siswa, namun pemilihan materi harus diperhatikan dan disesuaikan. Siswa tidak hanya diberikan menonton media audio visual tapi mencermati isi dari audio visual dan mendengarkan, mencatat, siswa juga berperan aktif untuk bertanya, mengikuti latihan dalam mengasah kemampuan, serta merespons materi yang disampaikan. Selain itu, siswa yang kurang percaya diri dan masih ada perasaan takut salah ketika 
menggunakan bahasa Jepang serta kurang fokus mengikuti pelajaran diberikan motivasi serta arahan agar mengikuti pembelajaran. hal ini didukung oleh pernyataan dari Padmadewi, (2012) yang menyatakan bahwa prinsip utama dalam tahapan ouyourenshuu yang berbasis makna maka pembelajaran bahasa akan terjadi sendirinya. Oleh karena itu siswa diberikan kesempatan untuk menggunakan bahasa asing secara optimal karena akan sangat bermanfaat untuk perkembangan bahasa dan keterampilan siswa.

Berdasarkan prinsip ini, tahapan pengajaran bahasa komunikatif yang telah diterapkan di kelas X MIPA 1 SMA Negeri 1 Tampaksiring telah dapat meningkatkan kemampuan berbicara siswa dalam bahasa Jepang. Pada penerapannya siwa benar-benar mendapatkan kesempatan menggunakan bahasa secara komunikatif di dalam kelas tanpa merasa takut salah dalam pengucapannya. Latihan-latihan percakapan yang dilaksanakan di dalam kelas membantu siswa untuk meningkatkan kemampuan berbicara dalam bahasa Jepang. Dalam penerapan tahapan ouyourenshuu, guru bertindak sebagai fasilitator yang mengarahkan siswa untuk melaksanakan proses komunikasi menggunakan bahasa Jepang. Interaksi serta keaktifan siswa sangat diperlukan dalam metode ini. selain usaha guru dalam menciptakan suasana pembelajaran yang menyenangkan dan interaktif, diperlukan kesadaran dari pribadi siswa untuk berlatih menggunakan bahasa Jepang secara komunikatif.

\section{SIMPULAN}

Berdasarkan analisis terhadap data hasil penelitian tindakan kelas (PTK) pada siswa kelas X MIPA 1 SMA Negeri 1 Tampaksiring dengan menerapkan tahapan ouyourenshuu, dapat disimpulkan sebagai berikut.

1. Penerapan metode pengajaran bahasa komunikatif dengan berbantuan media audio visual dapat meningkatkan kemampuan berbicara bahasa Jepang siswa kelas X MIPA 1 SMA Negeri 1 Tampaksiring. Peningkatan tersebut terbukti pada hasil belajar siswa dilihat dari pretest, post-test I, dan post-test II. Rata-rata nilai siswa yang diperoleh pada pretest yaitu 23,81 dengan ketuntasan klasikal 18,18\%, sedangkan pada post-test I terjadi peningkatan dengan perolehan rata-rata 79,09 dan ketuntasan klasikal yang diperoleh yaitu $87,87 \%$, selanjutnya peningkatan kembali terjadi pada siklus II dengan perolehan rata-rata sebesar 91,81 dan jumlah klasikal yang diperoleh sebesar $100 \%$. Hal tersebut membuktikan bahwa, peningkatan yang terjadi pada hasil belajar siswa kelas X MIPA 1 bukan karena pengulangan materi namun karena diterapkanya tahapan ouyourenshuu. Selain itu, bukti lain yang menunjukkan terjadinya peningkatan adalah dari bentuk perubahan siswa yang terjadi ketika proses belajar mengajar berlangsung.

2. Respons siswa kelas X MIPA 1 SMA Negeri 1 Tampaksiring terhadap penggunaan metode pengajaran bahasa tahapan ouyourenshuu untuk meningkatkan kemampuan berbicara bahasa Jepang positif. Dari hasil kuesioner tertutup yang dilakukan pada siklus I diperoleh rata-rata skor yaitu 41,48, sedangkan hasil kuesioner tertutup yang dilakukan pada siklus II diperoleh ratarata skor sebesar 41,93. Tidak hanya kuesioner tertutup yang membuktikan bahwa respons siswa positif dengan penerapan metode pengajaran tahapan ouyourenshuu untuk meningkatkan kamampuan berbicara bahasa Jepang siswa, namun pada hasil kuesioner terbuka juga menunjukkan respons yang positif. Pada kuesioner terbuka terdapat 3 pertanyaan, hasil respons siswa pada pertanyaan pertama pada siklus I sebanyak $34,7 \%$ sedangkan pada siklus II sebanyak $51,5 \%$ dengan respons dapat meningkatkan kemampuan berbicara bahasa Jepang. Pada pertanyaan kedua disiklus I respons siswa 66,6\% sedangkan pada siklus II sebesar $69,69 \%$ dengan respons siswa tidak memiliki kendala ketika diterapakanya tahapan ouyourenshuu. Sedangkan hasil respons siswa pada pertannyan ketiga siklus I yaitu $33,3 \%$ dan untuk siklus II yaitu $48,48 \%$ 
dengan respons lebih sering diterapkanya tahapan ouyourenshuu. Selain hal tersebut, dengan diterapkanya tahapan ouyourenshuu membuat siswa lebih percaya diri dan termotivasi ketika berbicara mengunakan bahasa Jepang, ingatan pada materi lebih lama, dan siswa menjadi aktif ketika mengikuti proses pembelajaran.

\section{SARAN}

1. Bagi guru

Dari penelitian ini diharapkan dapat memberikan motivasi kepada guru untuk menerapkan metode pembelajaran yang dapat mengetahui sejauh mana siswa menguasai bahan pelajaran serta memberikan kesempatan kepada siswa untuk berlatih berkomunikasi menggunakan bahasa Jepang. tahapan ouyourenshuu juga dapat diterapkan di kelas yang heterogen. Hal tersebut terbukti dari penelitian ini, seluruh siswa mendapatkan nilai diatas KKM pada siklus II. Tidak hanya terlihat dari perolehan nilai di atas KKM, namun lebih spesifiknya hal tersebut terlihat dari peningkatan masing-masing individu mulai dari yang sangat meningkat, peningkatan normal, dan peningkatan yang sedikit.

\section{Bagi sekolah}

Penelitian ini dapat dijadikan sebagai kebijakan sekolah untuk meningkatkan kemampuan berbicara bahasa asing siswa, khususnya dalam pembelajaran bahasa Jepang, yang juga dapat diterapkan pada pembelajaran lain selain dengan materi yang diberikan.

\section{Bagi Peneliti Lain}

Hasil penelitian ini dapat dimanfaatkan sebagai bahan acuan dalam melaksanakan penelitian berikutnya dan dapat memaksimalkan upaya peningkatan keterampilan dalam berbicara bahasa Jepang. Penelitian mengenai penerapan tahapan ouyourenshuu dalam mempelajari bahsa Jepang hendaknya lebih dikembangkan dengan menggunakan metode atau media pembelajaran jenis lain oleh peneliti-peneliti selanjutnya. Namun dengan memperlihatkan hambatan-hambatan yang terjadi pada penelitian ini agar penelitian yang dilakukan dapat diperbaiki dan lebih disempurnakan, serta hasil penelitian ini dapat digunakan untuk menambah ilmu pengetahuan.

\section{DAFTAR RUJUKAN}

Arsjad, Maidgar G dan Mukti U.S. 1993. Pembinaan kemampuan Berbicara Bahasa Indonesia. Cetakan ketiga. Jakarta : Erlangga.

Ghazali, Syukur. 2010. Pembelajaran Ketrampilan Berbahasa dengan pendekatan Komunikatif-Interaktif. Bandung : PT Refika Aditama.

Padmadewi, Ni Nyoman. 2012. Strategi Pembelajaran Bahasa. Cetakan pertama. Undiksha press.

Sanjaya, W. 2009. Penelitian Tindakan Kelas. Bandung: Kharisma Putra Utama.

Sudana, M. A. 2017. Penerapan Model Pembelajaran Kooperatif Tipe Student Team Learning (STL) Berbantuan Kartu Huruf Doremi untuk Meningkatkan Penguasaan Huruf Katakana Siswa Kelas XI IPB2 SMA Negeri 1 Sawan tahun ajaran 2016/2017. Skripsi (tidak diterbitkan). Jurusan Pendidikan Bahasa Jepang, Undiksha Singaraja.

Wendra, I Wayan. 2012. Buku Ajar : penulisan karya IImiah. Singaraja. Universitas Pendidikan Ganesha. 